\title{
Çalışma Yaşamının Geleceği Kapsamında Yetenek Geliştirme: Turizm Endüstrisi
}

\section{Skill Development in Future of Work: The Case of Tourism Industry}

\author{
Demet Tüzünkan' ${ }^{1}$ ( )
}

\section{Öz}

Çalışma yaşamının geleceği, Uluslararası Çalışma Örgütü'nün 100. kuruluş yılında öne çıkardığı bir girişimdir. İçeriğinde insan kapasitesine yönelik yatırımların arttırılması, işyerlerinde yatırımların arttırılması ve insan onuruna yakışır iş yatırımlarının arttırıması amaçlarını içermektedir. Çalışma yaşamının geleceği kavramı, özellikle otomasyon ve teknolojik gelişmelerin insanların istihdam edilebilirliklerini etkileyen yeteneklerinin çağa uygun geliştirilmesine yönelik tavsiyede bulunmaktadır. İnsan onuruna yakışır iş ise tüm kadın ve erkeklerin eşit şartlar altında istihdam edildikleri, çalışma koşullarının düzgün olduğu, sosyal koruma ve sosyal diyalog kavramlarının yer aldığı bir çalışma sürecidir. Dolayısıyla çalışma yaşamının geleceği, insan onuruna yakışır işi kapsamakla beraber insanların yeteneklerinin değiştirilmesi ve geliştirilmesi vurgusunu da yapmaktadır. Çalışma, kavramsal bir çalışma olup, teknolojik yeniliklerin en çok etkilediği endüstrilerden biri olan turizm endüstrisindeki istihdama yönelik olası tehditlerini ve çözüm önerilerini yetenek geliştirme ve yetenek yönetimi açısından ele almaktadır. Çalışmada sırasıyla Uluslararası Çalışma Örgütü hakkında bilgi verilmiş, ardından insan onuruna yakışır iş ve modelleri aktarılmıştır. Çalışmanın geleceği başlığında ise yetenek geliştirme kavramı üzerinde durulmuş, yetenek geliştirme ise Endüstri 4.0 kapsamında detaylı incelenmiştir. Son olarak turizm endüstrisi çalışmanın geleceği açısından örnek endüstri olarak ele alınmış, olası tehditler ve yaratılabilecek firsatlara sonuç ve öneriler kısmında değinilmiştir.

\section{Anahtar Kelimeler}

Uluslararası Çalışma Örgütü, İnsan onuruna yakışır iş, Çalışmanın geleceği, endüstri 4.0., Turizm, Yetenek geliştirme

\section{Abstract}

The future of work is an initiative brought forward by the International Labor Organization on its 100th anniversary. It aims to increase investments in human capacity, increase investments in workplaces and increase business investments in terms of decent work. The future of work is particularly relevant with the development of the capabilities that affect the employability of all people under the threats of automation

1 Sorumlu Yazar: Demet Tüzünkan (Dr. Öğr. Üyesi), İstanbul Kent Üniversitesi, Sanat ve Tasarım Fakültesi, Gastronomi ve Mutfak Sanatları Bölümü, İstanbul, Türkiye. E-posta: demet.tuzunkan@kent.edu.tr ORCID: 0000-0003-0440-294X

Atıf: Tuzunkan, D. (2020). Çalışma yaşamının geleceği kapsamında yetenek geliştirme: Turizm endüstrisi. Sosyal Siyaset Konferansları Dergisi, 78: 205-227. https://doi.org/10.26650/jspc.2020.78.0031 
and technological developments. Decent work is a process in which all men and women are employed under equal and decent working conditions with social protection and social dialogue concepts. Therefore, the future of work includes decent work and emphasizes the need of change and development of people's skills. The study is a conceptual study and examines the potential threats and solutions on employment in the tourism industry, which is one of the industries most affected by technological innovations, in terms of skills development and skill management. In this study, information was given about the International Labor Organization and then decent work and models were conveyed. In the title of the future of work, the concept of skills development was emphasized and skill development was examined in detail within the scope of Industry 4.0. Finally, the tourism industry is considered as a model industry for the future of work and possible threats and opportunities are discussed in the conclusions and recommendations section.

\section{Keywords}

ILO, Decent Work, Future of work, Industry 4.0., Tourism, Skill Development 


\section{Extended Summary}

ILO, which was founded in 1919 with the belief that a permanent and world-wide peace can only be achieved through social justice, agreeing on the fair and safe working conditions of workers in industrialized countries. ILO is currently working with 185 member states and it is the only tripartite United Nations organization - including the government, employers and workers- and all parties have equal rights to say in decisions. The parties have been trying to meet the needs of working men and women by coming together to form basic working standards and to develop policies and programs. The general policies of the ILO are determined by the International Labor Conferences that are held annually. Decent Work includes equal opportunity in employment and work life, fair working conditions and social protection for all women and men and social dialogue which was first mentioned in the report presented at the 87 th. International Labor Organization Conference in 1999. Decent work has four strategic objectives. The first objective covers the basic principles and rights at work. The second objective is to increase income opportunities for all women and men through more employment. In this aim, it was emphasized that poverty and inequalities can only be reduced by increasing employment. The third objective addresses social protection. Social protection is important in situations where the economy is fragile. The fourth and final objective is about social dialogue, representativeness and tripartite reconciliation. In 2003, models with various indicators and sub-criteria were developed by different experts to measure decent work within a country, region or just in an industry. The indicators and sub-criterias were finalized by the ILO in 2008 . All the previously developed models were basically similar to each other and all involved a fairer, better working environment.

2019 is the 100th anniversary of the ILO, and the ILO sees this anniversary as an opportunity for the future. In 2013 at the 102nd ILO conference, seven initiative titles were proposed for the 100th anniversary. These initiatives were approved by the management and it was emphasized that the future of work should be the focus point of the 100th year. Future of work discusses topics such as decent work policies for all, integration of young people with high qualified, productive and healthy working life, providing equal opportunity without gender discrimination, improvement of working conditions and social dialogue. In addition, it is underlined that the existing and potential gaps in skills and abilities should be identified and education and training systems 
should meet the needs of the labor market. People-oriented approach includes the concept of social dialogue, productive workplaces and safe and healthy working conditions necessary for decent work. Therefore, the future of the work, which has similar content with decent work, emphasizes the importance of skills development as a distinction of decent work.

Skill is defined as the way people apply their thoughts, feelings and acting abilities that they use repeatedly while producing a job. Throughout history, the skills and skills required by employees have also changed. Works in the early periods required more simple and routine skills, today, due to technological developments, they have turned into jobs that require flexibility, creativity, problem-solving skills and complex communication skills. Therefore, organizations need to manage these skill changes.

Approximately half of the current jobs and $60 \%$ of the professions can be done with technology. It is foreseen that $35 \%$ of the skills demanded for jobs in all industries will vary by 2020 . Education and training systems need to keep up with the new demands of constantly challenging labor markets with technological and demographic changes, changing business models and the changing nature of work. However, employers state that education systems cannot keep up with the changing nature of the job and that they cannot find enough staff with the needed skills. Investments and innovations are urgent and indispensable for the global labor market, to provide new skills to employees because the market is facing the challenges of technological changes. One of the industries in which new talents should be created or existing talents should be changed is tourism within the services industry. Tourism industry employment, which does not have very positive results for every indicator in terms of decent work, is also threatened by technology and developments in the 4th Industrial Revolution. Skills development, which is dealt with in the future of work, should be planned and implemented immediately in the tourism industry to prevent potential threats from Industry 4.0. based technologies. The tourism industry will not be affected by technological threats by increasing developing skills, adding new skills to existing ones or gaining skills. 


\section{Çalışma Yaşamının Geleceği Kapsamında Yetenek Geliştirme: Turizm Endüstrisi}

Uluslararası Çalışma Örgütü (UÇÖ), 1914-1918 yılları arasında süren I. Dünya Savaşı'nın hemen ardından 1919 yılında Cenevre'de kurulmuştur. Kalıcı ve dünya çapında bir barış ortamının ancak sosyal adalet ile sağlanabileceği inanciyla kurulan UÇÖ’nün ilk üyeleri Belçika, Küba, Çekoslovakya, Fransa, İtalya, Japonya, Polonya, Birleşik Krallık ve ABD olmuştur (ILO, ILO’nun tarihçesi). Kurulduğu dönemdeki zor çalışma şartlarını da göz önünde bulundurarak, devlet, işçi ve işverenin bir araya getirildiği bir organizasyon olan UÇÖ'nün kurucu üyeleri, sanayileşen ülkelerdeki çalışanların adil ve güvenli bir şekilde çalışmaları hususunda fikir birliği içindedirler. Ayrıca ülkelerin birbirlerine ekonomik bağımlılığı ve bu sebeple dünya istihdam piyasasındaki herkesin eşit çalışma şartları içinde olmaları gerektiği de bu dönemde vurgulanmıştır. Nitekim 1920 yılında 9 adet UÇÖ sözleşmesi ve 10 adet tavsiye kararı da aşağıdaki başlıklar kapsamında kabul edilmiştir (ILO, History of ILO).

- Çalışma saatleri

- İşsizlik

- Doğum korumasi

- Kadınlar için gece işleri

- Minimum yaş

- Gençler için gece işleri

Günümüzde, içinde Türkiye'nin de bulunduğu 185 üye ülke ile çalışmalarını sürdüren UÇÖ, içinde hükümet, işveren ve işçi taraflarının yer aldığı üç ayaklı tek Birleşmiş Milletler kuruluşu olup tüm taraflar alınacak kararlarda eşit söz hakkına sahiptir. Taraflar, kurulduğu ilk dönemlerden itibaren temelde çalışma standartları oluşturmak, politikalar ve programlar geliştirmek üzere bir araya gelerek çalışan kadınların ve erkeklerin ihtiyaçlarının karşılanmasını sağlamaya çalışmaktadır (ILO, ILO Nasıl Çalışır).

UÇÖ'nün üzerinde hassasiyetle durduğu temel noktalar; çalışanların cinsiyetine bakılmaksızın ayrımcılığa uğramadığı, temsil edilme hakkını kullanabildiği, çocukların ve gençlerin istismar edilmediği güven ve barış dolu 
bir iş ortamı içinde olmaları gerektiğidir. Uluslararası çalışma standartları ve UÇÖ’nün genel politikaları her yıl toplanan Uluslararası Çalışma Konferansı tarafindan belirlenmektedir.

İnsan onuruna yakışır iş, insana yakışır iş, (Düzgün İş) - Decent Work, 87. Uluslararası Çalışma Örgütü Konferansı'nda (1999) sunulan raporda ilk defa gündeme gelmiştir. İnsan onuruna yakışır iş, tüm kadınlar ve erkekler için istihdamda ve iş hayatında firsat eşitliği, sosyal koruma, sosyal entegrasyon, adil çalışma koşulları gibi başlıkları içermektedir (ILO, Decent Work).

\section{İnsan Onuruna Yakışır İş}

1999 yılında yapılan 87. UÇÖ Konferansı'nda sendikalı, sendikasız, yaşlı genç ayrımı yapılmadan herkesin insan onuruna yakışır işe sahip olmasının insan haklarının bir gereği olduğunun altı çizilmiştir. Bir işin insan onuruna yakışır olabilmesi için zorla çalıştırma ve çocuk işçiliğinin olmaması, yapılan iş karşılığında hak edilen ücretin alınabilmesi ve çalışmaya ilişkin temel hak ve ilkelerin üç taraflı uzlaşma - hükümet, işçi ve işveren - yani sosyal diyalog kapsamında gerçekleştirilmesi gerekmektedir (Tüzünkan, 2015, 7). Palaz'a (2005) göre, insan onuruna yakışır iş, tüm insanların ayırım yapılmaksızın çalışma, istihdam edilme, sosyal güvenlik, ifade ve temsil haklarına sahip olduklarına göndermede bulunan bir kavramsal çerçeveyi içermektedir.

İnsan onuruna yakışır işin dört stratejik hedefi vardır. İlk hedef, iş yerindeki temel ilkeleri ve hakları kapsamaktadır. İkinci hedef, daha fazla istihdam ile tüm kadın ve erkeklerin gelir firsatlarının arttırılmasına yönelik olan hedeftir. $\mathrm{Bu}$ hedefte yoksulluğun ve eşitsizliklerin azaltılmasının ancak istihdamın arttırılması ile mümkün olabileceği vurgulanmıştır. Üçüncü hedefte sosyal koruma ele alınmaktadır. Ekonominin değişken olduğu durumlar için sosyal koruma önem arz etmektedir. Dördüncü ve son hedef ise sosyal diyalog, temsil edilebilirlik ve üçlü uzlaşmalar ile ilgilidir (ILC87, Decent Work).

2003 yılında, insan onuruna yakışır işi bir ülke, bölge veya sadece bir endüstri kapsamında ölçebilmek için çeşitli göstergeler ve alt kriterler içeren modeller farklı uzmanlar tarafindan oluşturulmuştur. Tablo 1'de hem uzmanların hem de UÇÖ’nün insan onuruna yakışır iş kavramının içinde yer alan göstergeler bulunmaktadır. 
Tablo 1

İnsan Onuruna Yakışır İş Kavramına Yönelik Geliştirilen Modeller ve Göstergeler

\begin{tabular}{|c|c|c|c|c|c|}
\hline Göstergeler & Ghai & Bonnet & Bescond & Anker & ILO \\
\hline İstihdam & $\mathrm{X}$ & $\mathrm{X}$ & & $\mathrm{X}$ & $\mathrm{X}$ \\
\hline Sosyal Koruma & $\mathrm{X}$ & & & $\mathrm{X}$ & \\
\hline Çalışanların Hakları & $\mathrm{X}$ & & & & $\mathrm{X}$ \\
\hline Sosyal Diyalog & $\mathrm{X}$ & & & $\mathrm{X}$ & \\
\hline Emek Piyasası & & $\mathrm{X}$ & & & \\
\hline Meslek & & $\mathrm{X}$ & & & \\
\hline Çalışma & & $\mathrm{X}$ & & & \\
\hline Yetenek Geliştirme & & $\mathrm{X}$ & & & \\
\hline Gelir & & $\mathrm{X}$ & & & $\mathrm{X}$ \\
\hline Temsil Edilebilirlik & & $\mathrm{X}$ & & & \\
\hline Kayıtdışı İstihdam & & & $\mathrm{X}$ & & \\
\hline Düşük Ücretlerle Çalışanlar & & & $\mathrm{X}$ & & \\
\hline Çalışma Saatleri & & & $\mathrm{X}$ & $\mathrm{X}$ & $\mathrm{X}$ \\
\hline Yetkinlik Geliştirme & & & & $\mathrm{X}$ & \\
\hline İşsizlik Oranı & & & $\mathrm{X}$ & & \\
\hline Genç İşsizlik Oranı & & & $\mathrm{X}$ & & \\
\hline Emekli Olmayan Yaşlı Çalışanlar & & & $\mathrm{X}$ & & \\
\hline İstihdamdaki Erkek Kadın Oranlarının Farkları & & & $\mathrm{X}$ & & \\
\hline Kariyer ve İstihdam Güvencesi & & & & $\mathrm{X}$ & \\
\hline İstikrar ve İş Güvencesi & & & & $\mathrm{X}$ & $\mathrm{X}$ \\
\hline İş ve Aile Hayatı Dengesi & & & & $\mathrm{X}$ & $\mathrm{X}$ \\
\hline İstihdamda Adil Davranışlar & & & & $\mathrm{X}$ & $\mathrm{X}$ \\
\hline İş Güvenliği & & & & $\mathrm{X}$ & $\mathrm{X}$ \\
\hline Hükümsüz İşler & & & & & $\mathrm{X}$ \\
\hline Sosyal Güvenlik & & & & & $\mathrm{X}$ \\
\hline
\end{tabular}

Kaynak: Tüzünkan, 2015, Yayımlanmamış doktora tezi, İstanbul Üniversitesi Sosyal Bilimler Enstitüsü

İnsan onuruna yakışır işin ölçülebilmesi için geliştirilen ilk model olan Ghai modeli, insan onuruna yakışır işin hedeflerine bağlı kalarak oluşturulmuştur. İstihdam, sosyal koruma, çalışanların hakları ve sosyal diyalog kavramlarını içermektedir. Bu modele göre, işgücü katılım oranı, işsizlik oranı ve Gini katsayısına istihdam yaratma hedefinin ölçülmesinde, sosyal korumaya yönelik kamu tarafından yapılan harcamaların oranına ise sosyal koruma hedefinin ölçülmesinde bakılmaktadır. Çalışanların haklarına yönelik ölçüm için önerilen göstergeler; kadın işgücü katılım oranı, beyaz ve mavi yakalı çalışan kadın sayısı ve kadın işsizlik oranlarıdır. Son olarak bu modelde sosyal diyalog hedefi ise, sendikalaşma oranlarıyla ölçülmektedir (Ghai, 2003, 136).

İnsan onuruna yakışır işin ölçülmesine yönelik yapılan bir diğer çalışma, Bonnet, Figueiredo ve Standing'e aittir. Araştırmacılar, istihdam göstergesini Ghai gibi ölçüm aracı olarak görmekle beraber Ghai'den farklı olarak yedi 
temel gösterge üzerinde durmuşlardır. İstihdam dışında, emek piyasası, meslek, çalışma, yetenek geliştirme, gelir ve temsil edilebilirlik göstergelerini de ele almışlardır. Bu göstergelerin oluşturulmasında Birleşmiş Milletler Gelişme Programı'nda yer alan İnsani Gelişim Göstergeleri'nden faydalanılmıştır (Tüzünkan, 2015, 21). Araştırmacılar, bir kişinin istihdam güvencesine sahip olmasıyla iş güvencesine sahip olmasının birbirinden farklı olduğunun altını çizmektedirler. İnsanlar aynı iş yerinde dahi yeteneklerinin altında veya üstünde görevlerde çalışmaya zorlanabilmektedirler. Araştırmacılara göre insan onuruna yakışır iş bakımından güvenlik, istihdam açısından olduğu kadar yetenekler için de geçerli olmalıdır (Bonnet, vd., 2003, 214).

Bescond, Chataignier ve Mehran tarafindan oluşturulan üçüncü modelde yer alan göstergeler, ülkelerin istatistik veri tabanlarından rahatlıkla elde edilen verilerdir. Araştırmacılar insan onuruna yakışır iş kavramını hedefleri doğrultusunda genel bir çerçevede ölçmek yerine daha spesifik bir ölçüm için detaylı göstergeleri ele almışlardır. Bunlar; kayıt dışı istihdam oranı, düşük ücretlerle çalışanların oranı, çalışma saatleri, işsizlik oranı, genç işsizlik oranı, istihdamdaki erkek-kadın oranlarının farkları, emekli olmayan yaşlı çalışanların oranı olmak üzere yedi adettir (Bescond vd, 2003, 207). Ölçüm için önerilen göstergelerin insan onuruna yakışır iş hedeflerinden istihdam, sosyal koruma ve çalışanların haklarına yönelik göstergeler olduğu görülmekte, sosyal diyalog veya çalışanların temsil edilebilirliğine yönelik bir ölçümden ise söz edilmemektedir.

Anker, Chernyshev, Egger, Mehran ve Ritter 2003 yılında yaptıkları çalışmada insan onuruna yakışır işin ölçümünde kullanılabilecek 11 gösterge olduğunu ileri sürmüşlerdir. Bunlar; istihdam firsatları, çalıştırılma yasağı olan kişiler ve işler, yeterli gelir getiren ve üretken işler, uygun çalışma saatleri, iş güvencesi, iş ve aile yaşamı dengesi, istihdamda eşitlik, işçi sağlığ1 ve iş güvenliği, sosyal koruma, sosyal diyalog ve işyerinde ilişkiler, ekonomik ve sosyal koşullar olarak sıralanmıştır (Tüzünkan, 2015, 22-23). Bu göstergeler, istihdam, sosyal koruma ve sosyal diyalog, çalışma saatleri açısından diğer araştırmacılar ile ortak başlıklar içermekle birlikte kariyer ve istihdam güvencesi, istikrar ve iş güvencesi, iş ve aile hayatı dengesi, istihdamda adil davranışlar, iş güvenliği ve yetkinlik geliştirme açısından ilk defa ele alınmaktadır. Araştırmacılar bu çalışmalarında insan onuruna yakışır işis; iş firsatları, çalışma özgürlügü, üretken iş, çalışma hayatında eşitlik ve saygınlık ve iş güvencesi kapsamında ölçümlemektedirler (Anker, 2003, 154). 
İnsan onuruna yakışır işin ölçülebilmesi için UÇÖ tarafından 2008 yılında geliştirilen son model, Anker ve arkadaşlarının ortaya koydukları göstergelerden oluşturulan modelle büyük benzerlik içermektedir. Modeldeki göstergeler sadece ulusal ve uluslararası istatistik veri tabanlarındaki istatistiklerle değil, aynı zamanda yasal bir çerçeveye de oturtularak UÇÖ sözleşmeleri ve tavsiye kararları kapsamında da değerlendirilmektedir. Bu modelde yer alan göstergeler şu şekildedir (ILO Manual, 2013),

1. İstihdam Firsatları

2. Uygun Kazanç ve Verimli Çalışma

3. Düzgün Çalışma Saatleri

4. İş ve Aile Yaşamı Dengesi

5. Hükümsüz İşler

6. İstikrar ve İş Güvencesi

7. İstihdamda Eşit Fırsatlar ve Davranışlar

8. Güvenli İş Ortamı

9. Sosyal Güvenlik

10. Sosyal Diyalog ve Çalışanların Temsil Edilebilirliği

Anker ve arkadaşlarının modelinden farklı olarak bu modelde çocuk işçiliği ve zorla çalıştırma konularını içeren hükümsüz işler göstergesi yer almaktadır. $\mathrm{Bu}$ gösterge, daha önce Anker ve arkadaşlarının modelinde sadece çocuk işçiliğini konu alan yetkinlik geliştirme olarak geçmektedir. $\mathrm{Bu}$ farklılığın yanı sıra Anker ve arkadaşlarının modelinde yer alan kariyer ve istihdam güvencesi göstergesi kazançlar ve ücretler konularında alt kriterlere sahipken, UÇÖ tarafından geliştirilen modelde ücretler konusu, uygun kazanç ve verimli çalışma başlığı altında ayrı bir gösterge olarak ele alınmakta, istikrar ve iş güvenliği adlı göstergede ise, istikrarsız işlerde istihdam ve fesih şartları değerlendirilmektedir (Tüzünkan, 2015, 25).

Tüm modellere bakıldığında modellerin içerdikleri konuların hem genel, hem özel çerçevede birbirlerine benzemelerine rağmen Bonnet ve arkadaşlarının modelinde yer alan yetenek geliştirme kriterinin diğer hiçbir 
modelde yer almadığ 1 görülmektedir. Bu konunun, 2019 yılında çalışmanın geleceği (future of work) kapsamında UÇÖ’nün detaylı bir şekilde ele alındı̆̆g görülmektedir.

\section{Çalışmanın Geleceği}

2013 yılında yapılan 102. UÇÖ konferansında kuruluşun 100.yılında ele alınmak üzere yedi adet girişim başlı̆̆ önerilmiştir. Bu başlıklar; yönetişim, standartlar, yeşil, işletmeler, yoksulluğun bitirilmesi, çalışma yaşamında kadın ve çalışmanın geleceğini (future of work) içermekte olup çalışmanın geleceği kavramı ilk defa bu konferansta gündeme getirilmiştir (ILO, Report IV, 2019). Sonrasında bu girişim önerileri yönetim tarafından onaylanmış olup özellikle çalışmanın geleceği başlığının 100. yılın odak noktası olması gerektiği vurgulanmıştır (ILO, 2015).

2015 yılında yapılan 104. UÇÖ Konferansı'nda çalışmanın geleceği girişiminin üç aşamadan oluşan bir uygulama planı içinde gerçekleşmesi öngörülmüştür. İlk aşamada 110'dan fazla UÇÖ üyesi, çalışmanın geleceği kapsamında işçi, işveren ve hükümet taraflarının katılımlarıyla üçlü diyaloglar gerçekleştirmiş ve çalışmanın geleceğini; çalışma ve toplum, herkes için insan onuruna yakışır iş, çalışma ve üretimin organizasyonu ile çalışmanın yönetişimi olmak üzere dört ayaklı bir temele dayandırmıştır (ILO, Report IV, 2019).

İkinci aşama, 2017 yılının Ağustos ayında UÇÖ küresel komisyonunun çalışmanın geleceği hakkında ilk defa toplanmasıyla gerçekleşmiştir. $\mathrm{Bu}$ toplantıda çalışmanın geleceğinin güvenlik, eşitlik ve refah sağlaması gerektiği belirtilmiş, bu konuda farklı başlıkları içeren yönelik altı ayrı takım oluşturulmuştur. Bu başlıklar aşağıdaki şekildedir (ILO, Future of Work Issue Briefs):

- Bireyler ve toplum açısından çalışmanın rolü

- İşyerlerindeki kadın eşitsizliklerinin son bulması

- Sosyal, çevresel ve ekonomik gelişim açısından teknoloji

- Eğitimin her aşamasında değişimi yönetme

- Büyüme ve gelişmeye yönelik yeni yaklaşımlar

- Gelecekte çalışmanın yönetişimi 
Küresel komisyon toplam dört defa toplanmış ve 22 Ocak 2019 tarihinde "Daha Parlak Bir Gelecek İçin Çalışmak" - (work for a brighter future)isminde bir rapor sunmuştur. Üçüncü ve son aşamada UÇÖ, üyelerini küresel komisyonun raporunu göz önünde bulundurarak etkinlikler düzenlemelerine teşvik etmiştir (ILO, Report IV, 2019). 108.UÇÖ Konferansı'nda çalışmanın geleceğinin insan odaklı bir yaklaşım içermesi gerektiği vurgulanmıştır. Çalışmanın geleceğinde, herkes için insan onuruna yakışır iş politikalarının kapsanması, gençlerin eğitimlerle, yaşlıların kaliteli, verimli ve sağlıklı bir şekilde iş yaşamına entegre edilmesi, cinsiyet ayrımcılığı yapılmadan fursat eşitliği sağlanması, temsil edilebilirliğin özgürce işlerlik kazanması, çalışma koşullarının iyileştirilmesi gibi başlıklar ana hatlarıyla ele alınmıştır. Ayrıca yeteneklerdeki farklılıkların tespit edilmesi ile eğitim ve öğretim sistemlerinin işçi pazarının ihtiyaçlarına cevap vermesinin gerekliliğinin de altı çizilmiştir. İnsan odaklı yaklaşım, içeriğinde; sosyal diyalog kavramını, verimli iş yerlerini ve insan onuruna yakışır iş için gerekli olan güvenli ve sağlıklı çalışma koşullarını da kapsamaktadır (ILC 108, 2019).

Küresel komisyon, çalışmanın geleceğine yönelik hazırlamış olduğu 2019 y1lı raporunda çalışmanın geleceğinin üç ana konuyu içerdiğini belirtmiştir. $\mathrm{Bu}$ konular; yapay zekâ otomasyon ve robotlar gibi teknolojik gelişmelerin yeni meslekler ve işler yaratacağına, bu değişimlere uymayan yetenek ve becerilerin çalışma yaşamından silineceğine, ayrıca bazı bölgelerde gençleşen, bazı bölgelerde ise yaşlılaşan nüfusun da istihdam pazarında ve sosyal güvenlik sistemlerinde değişimler yaratacağına yöneliktir (Global Commission, 2019).

İnsan onuruna yakışır işin ölçülebilmesi için önerilen modeller arasında yalnızca Bonnet ve arkadaşlarının önerdiği modelde ele alınmış olan yetenek geliştirme, ilk defa 16 yıl aradan sonra çalışmanın geleceği kapsamında ele alınmaktadır. Küresel komisyon raporunda insanların kapasitelerinde yatırımların arttırılması, işyerlerinde yatırımların arttırılması ve insan onuruna yakışır ve sürdürülebilir çalışma yatırımlarının arttırılması şeklinde üç başlık altında önerilerini sunmuşlardır. İnsanların kapasitelerindeki yatırımların arttırılmasi; yetenek ve becerilerin geliştirilmesi için yaşam boyu eğitimi, gelecekteki işlere geçiş için gençlere ve yaşl1lara çeşitli politikalarla desteği, cinsiyet eşitliğinin uygulanmasını ve doğumdan ölüme kadar küresel bir sosyal koruma sisteminin gerekliliğini içermektedir. İşyerlerinde yatırımların 
arttırılması; temel çalışma haklarını benimseyen küresel bir istihdam garantisi kurabilmeyi, iş ve aile yaşamı dengesi sağlayabilmeyi, sosyal diyalog hakkını korumayı ve teknolojiyi insan onuruna yakışır işe uyumlu hale getirmeyi amaçlamaktadır. Bunun da ancak insan yönetiminde olan bir yapay zekâ anlayışı ile mümkün olabileceğini belirtmişlerdir. Çalışmanın geleceğine dair ele alınan son başlık ise insan onuruna yakışır ve sürdürülebilir çalışma yatırımlarının arttırılmasıdır. Bunun da gelecekteki istihdamda kilit rol oynayabilecek alanlara yatırım teşviklerinin arttırılması ile insanların refah ve gelişimleri için uzun vadeli yatırım yaklaşımlarının benimsenmesi sayesinde mümkün olabileceğini vurgulamışlardır (Global Commission, 2019).

Günümüzde dünyada 200 milyonun üzerinde kayıtlı işsiz insan bulunmaktadır ve her y1l 40 milyonun üzerinde insan istihdam pazarına katılmaya devam etmektedir. 2030 yılına kadar ekonominin yaklaşık 600 milyon yeni iş yaratması gerekmektedir ki bunun yaklaşık yarısı sadece hizmetler sektörüne ait olacaktır. İnsanlar günümüzde dahi yoksulluk sınırlarında, temel çalışma haklarından muzdarip, sosyal güvencesiz şekilde çalışmaktayken daha fazla insanın bulunacağı istihdam pazarında gelecek için önlemler alınması gerekmektedir. UÇÖ, bu tedbirler arasında öncelikli olarak yetenek ve becerilerin geleceğe ve teknolojik değişimlere uyumlaştırılması ve buna bağlı olarak kişilerin, en az gelişmiş ekonomilerde bile, istihdam edilebilirliklerinin arttırılması yoluna gidilmesi gerektiğinin altını çizmektedir (ILO, 2015).

Ulaştırma, bilgi ve iletişim alanlarında yaşanan teknolojik gelişmeler, sadece işlerin yok olmasına veya yeni işler yaratılmasına sebep olmamakta, aynı zamanda mevcut işlerin yapılarının değişerek yeni meslekler ve dolayısıyla yeni istihdam yaratılmasını da sağlamaktadırlar. UÇÖ, çalışmanın geleceği kapsamında yayımladığı teknolojik gelişmelerin istihdama etkisine yönelik raporunda, istihdamdaki herkesin doğru yeteneklere sahip olması gerekliliğini ve teknolojik gelişmelerin hangi yeteneklere ihtiyaç duyulacağının tam olarak bilinmediğini vurgulamakla birlikte eğitim ve öğretim sistemlerinin bu yöndeki yetenek geliştirme süreçlerindeki önemine dikkat çekmektedir (ILO, Future Of Work Issue Note Series 1, 2019).

\section{Yetenek Geliştirme Kapsamında Endüstri 4.0.}

18. yüzyılda İngiltere'de buharlı makineler ile başlayan 1. Sanayi Devrimi, 20. yüzyılın başlarında fabrikalarda elektrik kullanımı ile yerini 2. Sanayi 
Devrimi'ne bırakmıştır. 1970'lerden günümüze kadar olan süreci kapsayan ve dijital süreci kapsayan 3. Sanayi devriminin ardından ise Endüstri 4.0. olarak da tanımlanan 4. Sanayi Devrimi nesnelerin interneti (IoT) üzerinden bulut teknolojileri ve dijital teknoloji kullanımı olarak bilinmektedir (Gurun, 2019, 70-71). Endüstri 4.0. ile gelişmekte olan teknolojiler daha geniş veri iletişimine ve genişleyen bilgi ağına ulaşmaktadır (Sarı, 2018, 35).

Teknolojinin hem mikro hem de makro düzeyde büyüme ve verimliliğe katkı sağlaması için ülkelerin teknolojiyi daha yüksek gelir sağlama ve istihdam yaratma açısından kullanabilecekleri tutarlı politik reformlara ihtiyaçları bulunmaktadır. Bu politikalar teknolojiyi eğitim ile birleştirici, yetenekler açısından istihdamdaki arz ile talebi dengeleyici ve bu sayede istihdam edilebilirliği arttırıcı olmalıdır (OECD, Highlights). Bazı ekonomistler, yeni teknolojilerin kısa dönemde büyük oranda işsizlik yaratacağını savunmaktadırlar. Bu ekonomistler, bazı işlerin sonsuza dek yok olacağını ama doğru eğitimlerle yeteneklerin geliştirilmesi durumunda uzun dönemde insanların işsiz kalmayacaklarını öne sürmektedirler. Bazı ekonomistler ise bu durumdan çok emin değillerdir. Günümüzde otomasyon, yapay zekâ ve robotları kapsayan istatistiklere bakıldığında 2014 yılından beri işini kaybetmekten endişe eden insanların sayısının \%3 arttı̆̆ 1 görülmekte olup, yapılan araştırmaya göre çalışanların \%70’i yüksek yetenek ve eğitim gerektiren işlerde istihdamın olacağını düşünmektedirler. $\mathrm{Bu}$ sebeple, Dünya Ekonomik Forumu, 2022 yılına kadar \%54'den fazla çalışan insanın yeteneklerinin yeniden düzenlenmesi ve/veya geliştirilmesi gerekeceğini vurgulamıştır (Dautovic, 2019).

Yetenek; insanların bir işi üretirken tekrar tekrar kullandıkları düşünme, hissetme ve davranma yetilerinin uygulanma biçimi olarak tanımlanırken, yetenek yönetimi; bir örgütün zorluklarla mücadele etmek ve vizyon, misyon ve hedeflerini gerçekleştirmek amacıyla stratejik planlarını hayata geçirmek için doğru yetenekte personeli seçmesi ve yetiştirmesi olarak ifade edilmektedir (Gurun, 2019). Dolayısıyla yetenek ve yetenek yönetiminin merkezinde insan vardır demek yanlış olmamaktadır. 1. Sanayi Devrimi'nden 4. Sanayi Devrimi'ne çalışanlarda olması gereken yetenek ve beceriler de değişim göstermiştir. Nitekim işler de üretilen ilk basit makinelerdeki gibi açma, kapama, döndürme gibi rutin beceriler gerektiren işlerden günümüzde esneklik, yaratıc1lık, problem çözme becerileri ve karmaşık iletişim yetenekleri 
gerektiren işlere dönüşmüşlerdir (Nübler, 2016). Dolayısıyla örgütlerin yetenek değişimlerini de yönetebilmeleri gerekmektedir.

Endüstri 4.0.'in başarılı olması, 4 temel yetenekle ilişkilendirilmiştir. Teknolojik, ekonomik, çevresel ve sosyal zorluklarla baş edebilmek için işletmelerin süreç, medya, kodlama ve bilgi teknolojileri güvenliği gibi teknik yeteneklere; yaratıcılık, girişimcilik, problem ve çatışma çözme, karar verme, analitik düşünebilme ve araştırma yapabilme gibi metodolojik yeteneklere; kültürlerarası iletişim, yabancı dil, takım çalışması, bilgi aktarımı ve liderlik gibi sosyal yeteneklere ve esneklik, tolerans, öğrenme motivasyonu, baskı altında çalışabilme ve uyum gibi bireysel yeteneklere sahip olmaları gerekmektedir (Gurun, 2019).

McKinsey\&Company şirketinin 2018 yılında yayımladıkları araştırmalarına göre 2030 y1lına kadar bilgi teknolojileri ve programlama yetenekleri gibi teknolojik yeteneklere sahip çalışanlara yönelik talepte \%90'a yakın artış beklenmektedir. Ayrıca temel dijital yeteneklere ihtiyaç için de ABD'de \%69, Avrupa'da \%65 düzeyinde artış olacağı öngörülmektedir. İleri teknolojilerin iş yaşamına adapte olmalarının ardından tüm endüstrilerde, empati, güçlü iletişim, ince düşünebilme gibi sosyal ve duygusal yeteneklere sahip olan çalışanlara talepte de artış olacağı düşünülmektedir (ABD- \%26, Avrupa\%22). Girişimcilik yeteneğinin de istihdamda yüksek talep görecek bir metodolojik yetenek olacağı da raporda yer almaktadır (ABD-\%33, Avrupa\%32). 2030 yılına kadar ABD'de \%19, Avrupa'da \%14 oranında talep artış1 olacağı öngörülen bazı yetenekler de yaratıcılık, eleştirel düşünebilme, karar verme ve karmaşık bilgi süreçlerini yönetebilme yetenekleridir. Özellikle fiziksel ve manuel yeteneklere olan ihtiyaçların 2030 yılına kadar ABD'de ve Avrupa'da ortalama \%14'e yakın düşeceği de raporda belirtilmektedir (McKinsey\&Company, 2018).

Günümüzdeki mevcut işlerin yaklaşık yarısı ve mesleklerin \%60'a yakını teknolojiyle yapılabilmektedir. Dolayısıyla çalışanlar zamanlarının \%40'ını sürekli öğrenmeye, eğitime ve yaratıcılıklarını geliştirmeye ayırabilirler. Böylece gelecekte ihtiyaç kalmayacak fiziksel yetenekleri yerine bilişsel yeteneklerini arttrabilirler (European Commission, https://ec.europa.eu). Tüm endüstrilerdeki işler için talep edilen yeteneklerin \%35'inin 2020 yılına kadar değişeceği öngörülmektedir bu yüzden eğitim ve öğretim sistemlerinin teknolojik bozulma, demografik değişim, değişen iş modelleri ve işin değişen 
doğası ile sürekli zorlanan işgücü piyasalarının yeni taleplerine ayak uydurması gerekmektedir (https://www.closingtheskillsgap.org/). Ancak, işverenler, eğitim sistemlerinin işin değişen doğasına ayak uyduramadığını ve ihtiyaç duyulan yeteneklere sahip yeterli sayıda eleman bulamadıklarını belirtmektedirler. McKinsey şirketinin 9 ülkede yaptığı araştırmaya göre özellikle başlangıç seviyesindeki işler için başvuru yapan yeni mezunların değişen dünyaya ayak uydurabilecek kapasite, yetenek ve donanımla mezun olmamaları işsizliğe sebep olan sorunların başında gelmektedir (Manyika, 2017).

Yeteneklerin piyasadaki ihtiyaçlarla örtüşmemesi işsizliğin artmasına sebep olabilecektir. Bu nedenle gelecekte gerekliolabilecek yetenekleriöngörebilmek önem kazanmaktadır. UÇÖ ve OECD de dahil olmak üzere pek çok farklı kurum ve kuruluş tarafından tüm dünyada eğitim ve öğretime yatırımlar yapılmaktayken hala neden ihtiyaç duyulan yeteneklerin bulunamadığına dair araştırmalar yapılmaktadır. 1980 ve 1990'lı yıllarda dijitalleşme süreçlerindeki yeniliklerin çok hızlı olmasından ve yetenek temelli teknolojik değişimlerden ötürü yetenek kıtlığı bulunmaktayken 2000'li yılların ortalarından itibaren ihtiyaç duyulan yeteneklerin bulunamamasının sebebi olarak tekno-ekonomik paradigmalar gösterilmektedir. ABD'deki 1800'den fazla iş lideri, teknoloji uzmanı ve akademisyen katıldıkları bir çalışmada, eğitim sisteminin kişileri geleceğin çalışmalarına hazırlamayacağına ve siyasi ve ekonomik kurumların yeterince donanımlı olmadıklarına dair endişelerini dile getirmişlerdir. Ülkeler günümüzde kurumsal çerçevelerde reform yapmak ve yeni teknolojilere uyum sağlayabilmek için eğitim ve öğretim politikalarına yönelik yapısal değişim konularında zorlanmaktadırlar. Günümüzde eğitim ve öğretimde asıl mesele, "hangi becerilerin verilmesi gerektiği” değil, "işgücünün nasıl eğitileceğii" ve ekonominin yeni işler ile yeni sektörler yaratmasına olanak sağlayacak bilgi tabanını ve sosyal yetenekleri oluşturmak için hangi kurumlara ihtiyaç duyduğuyla ilgilidir (Nübler, 2016). Teknolojik işsizlik bir tehdit olsa da teknoloji sayesinde yeni işler ve meslekler de yaratılabilmektedir (ILO, 2017). Yeni işler, melez (hybrid) denilen farklı yeteneklerin bileşimlerini gerektirecek işlerdir. Büyük veri (big data) mimarları, bulut hizmetleri uzmanları, yasal bilgi mühendisleri ya da süreç analistleri gibi yeni meslekler birden fazla yeteneği içinde barındırmaktadır (Nübler, 2016). Çalışanlara yeni beceriler kazandırmak için yatırım ve yenilik yapmak teknolojik değişimin yarattığ1 zorluklarla mücadele etmekte olan işgücü piyasası için acil ve vazgeçilmezdir. Ama öncelikle hangi yetenekler gerekiyor, hangi kurumlar bu 
yeteneklere yönelik eğitimleri sağlayabilecek, maliyetleri kim karşılayacak ve kimler bu yeteneklere erişebilecek gibi soruların yanıtlarının bulunması gerekmektedir (MIT, 2019). Yeni yeteneklerin oluşturulması veya var olan yeteneklerin değişime uğraması gereken endüstrilerden biri, hizmet sektörü içinde yer alan turizm sektörüdür.

\section{Çalışmanın Geleceği: Turizm Endüstrisi Örneği}

Doğası gereği hem hizmet alan hem de hizmet sağlayıcı olarak iki yönlü insan odaklı olan turizm endüstrisinde değişiklikleri tahmin etmek çok kolay olmayıp turizm endüstrisinde bulunan alt sektörlerin hepsi büyük oranda insana bağımlıdır (UNWTO, 2014).

Turizm endüstrisinde istihdam üç bölümden meydana gelmektedir. İlk bölüm doğrudan turizm istihdamıdır. Bu istihdama örnek olarak havayolu şirketleri, oteller, taksiler ve araç kiralama şirketleri, restoranlar, mağazalar ve rekreasyon yerleri gibi turistle doğrudan iletişim halinde olan ve hizmet veren işletmelerde çalışanlar sayılabilir. İkinci bölüm, havayolu gıda tedarikçileri, çamaşırhane hizmetleri, toptancılar ve finans hizmeti sağlayıcıları gibi işletmelerinin ihtiyaç duyduğu mal ve hizmet girdilerini sağlayan sektörlerde çalışanlar olarak dolaylı turizm istihdamıdır. Üçüncü bölüm ise turizmden doğrudan ve dolaylı yollardan elde edilen gelirlerin yeniden harcanması ile ekonomide ortaya çıkan ve ek istihdam olarak da adlandırılan uyarılmış istihdamdır (Ünlüönen ve Şahin, 2011, 4). Dünya genelinde 2018 yılı verilerine göre 318 milyondan fazla kişiye istihdam olanağı yaratmış olan (küresel istihdamın \%10’u) turizm endüstrisinin yarattığı en önemli etkilerinden biri istihdama etkisidir (Turner, 2018, 8). Türkiye'de ise TÜİK verilerine göre 2018 yılında 18 faaliyet alanı arasında 6. sırada yer alan konaklama ve yiyecek hizmeti faaliyetleri altında toplam 1.618 .000 kişi istihdam edilmiş ve bu kişilerin 404.000'i kadın olup gerisi erkek çalışanlardır (TÜİK, İşgücü İstatistikleri). İnsan onuruna yakışır işin üzerinde titizlikle durduğu istihdamda eşit fırsatlar yaklaşımı bu rakamlarda görülmemekle beraber kantitatif olarak toplamda yüksek rakamların olduğu turizm endüstrisinde istihdam, kalitatif olarak incelendiğinde ortaya olumsuz bir tablo çıkmaktadır. İnsan onuruna yakışır iş göstergeleri açısından incelenen turizm istihdamında konaklama ve yiyecek-içecek faaliyet alanında çalışan kişilerin eğitim seviyesinde en yüksek oranın \%33,4 ile okuma-yazma bilen ve ilkokul eğitim seviyesinde 
olduğu 2018 TÜİK verilerinden ortaya çıkmıştır. Yüksek eğitim düzeyine sahip kişiler ise \%11,99 ile en düşük orandadır (TÜİK, İşgücü İstatistikleri). $\mathrm{Bu}$ veriler, çoğu işin yüksek bilgi ve beceri gerektirmeyen işler olması sebebiyle sektörün yapısına zıt bir durum teşkil etmemektedir. Kayıt dışı çalışmaların sıkça görüldüğü turizm sektöründe konaklama ve yiyecek-içecek faaliyet alanında oran 2018 yılında \%30,3’dür (TÜİK, İşgücü İstatistikleri). Yani hemen hemen her 3 kişiden biri kayıt dışı çalışmaktadır. Bunun sebebi, faaliyetlerin mevsimlik özellik taşıması, kendi hesabına çalışan ve ücretsiz aile işçisi istihdamının yoğun olması, çoğu yüksek bilgi ve beceri düzeyi gerektirmeyen işler olması sebebiyle eğitimsiz çalışan sayısının fazla olmasından kaynaklanmaktadir.

İnsan onuruna yakışır işin bir diğer göstergesi olan ücretler ve kazanç açısından bakıldığında ise TÜİK'in en son yayımladığı 2014 verilerine göre hem kadınlarda her erkeklerde yıllık brüt ücret konaklama ve yiyecek-içecek faaliyet alanında 17 faaliyet alanı içinde son sırada yer almaktadır. Haftalık çalışma saatleri bakımından ise 2016 yılında TÜİK verilerine göre 42,7 saat olsa da diğer faaliyet alanları içinde en yüksek çalışma saatleri arasında yer almaktadır (TÜIK, İşgücü Maliyeti). Sosyal diyalog ve sendikalaşma açısından ise turizm endüstrisinde sendikalaşma oranının 2018 ÇSGB istatistiklerine göre \%3,41 olduğu görülmektedir. Türkiye geneli sendikalaşma oranı ise 2017 y1lında \%11,95 iken 2018 yılında \%12,76’ya yükselmiştir (ailevecalisma.gov.tr).

Turizm endüstrisinde çalışanların istatistiklerden ve yasal çerçeveden elde edilen veriler 1şığında insan onuruna yakışır iş kriterlerine uyumlu olmayan çalışma koşulları içinde oldukları tespit edilmiştir (Tüzünkan, 2015). Ayrıca, turizm endüstrisi istihdamı teknolojiden ve 4. Sanayi Devrimi'nde yaşanan gelişmelerden kaynaklı olarak tehdit altındadır. UÇÖ’nün yayımladığı çalışmanın geleceği (future of work) kapsamında ele alınan yetenek geliştirme kavramının ivedilikle turizm endüstrisinde planlanıp uygulanmaya başlanmasının Endüstri 4.0. temelli teknolojilerin turizm istihdamında yaratabileceği olası tehditleri önleyebileceği düşünülmektedir.

Yapılan araştırmalara göre dijital teknolojiler, akıllı turizm (smart turizm) ile sosyal medya, internet ve bulut teknolojileri gibi web tabanl uygulamalar turistlerin tercih ve deneyimlerini etkilemektedir (Sar1, 2018). 2030 yılında turizm endüstrisinin bir kolu olan seyahat acentalarının yok olacağ1 öngörülmektedir. Zira, artık herkes kendi tatilini planlayabilme, 
ödemelerini çevrimiçi olarak yapabilme, tatil yerleri hakkında ve turistik tesisler hakkında bilgi edinebilme ve ulaştırma araçlarını seçip satın alabilme kolaylığı içindedir (Phillpott, 2017). Robotlar, yapay zekâ ve hizmet otomasyonunun turizm endüstrisine etkisini inceleyen bir başka çalışmada, bu teknolojilerin turizm endüstrisinde işgücü maliyetlerini azaltacağı, robotların insanlar gibi yasalar gereği haftada ortalama 40 saat değil, 7/24 ve her dilde anlaşarak çalışabilecekleri, mevsimsel istihdama gerek kalmayacağı, robotların karmaşık iş sözleşmelerine ve sendikalaşmaya gerek duymayacağı öngörülerek insanların istihdamlarının turizm endüstrisinde giderek azalacağının altı çizilmiştir (Ivanov ve Webster, 2017). Bir başka çalışma ise bu öngörüyü desteklerken robotların otellerde önbüroda, restoranlarda, concierge hizmetlerinde, havalimanlarında güvenlik ve destek hizmetlerinde, seyahat acentalarının müşteri ilişkileri ve rezervasyon bölümlerinde, kısacası turizm endüstrisinin hemen her faaliyet alanında olduğunu ve olacağını vurgulamaktadir (https://www.revfine.com/robots-hospitality-industry/).

Teknolojinin evrimiyle beraber tehdit altında olan turizm endüstrisi istihdamı konusunda gelecek için önlemler alınmalıdır. $\mathrm{Bu}$ konuda yapılan bir araştırmada, turizm öğrencilerinin mevcut ders programlarına girişimcilik, inovasyon, gibi dersler konularak yeteneklerinin geliştirilmesi yönünde adımlar atılması, ağırlama ve turizm işletmeciliği gibi disiplinlerin mühendislik disipliniyle ortak ders oluşumlarına gidilmesi gibi çözümler önerildiği belirtilmiştir (Ivanov, vd., 2019).

Teknolojiler bazı işleri yok ederken aynı zamanda başka yeni işler ve meslekler de yaratmaktadırlar. Örneğin istatistik ve veri analizcilerine olan ihtiyacın artacağ1 öngörülmektedir. Dijital teknolojiler sayesinde bireysel girişimcilerin de artacağı belirtilmiştir (Manyika, 2017). Dolayısıyla turizm endüstrisinde çalışmayı isteyenler için de teknik ve metodolojik yeteneklere önem verilmesi, bu alanlarda orta öğretim düzeyinden başlayarak eğitimlerin olması, turizm ders programlarına teknoloji derslerinin konularak mezun olunmadan önce çok disiplinli ve gelecek odaklı uzun vadeli planların yapılması uygun olacaktır.

Birleşmiş Milletler, 2010 yılında turizm istihdamı ile ilgili çeşitli ülkelerle görüşmeler yaparak bir araştırma raporu sunmuştur. Türkiye'de bu konuda bilgi veren ülkelerden biridir. Türkiye, turizm ve istihdam ilişkisinde istihdam edilebilirlik, girişimcilik, hizmet kalitesi, bilgi eğitimi, kalite ve çalı̧̧anların 
çalışma çevreleri konularına önem verdiğini belirtmiş ve bu konulara 2023 Turizm Strateji planında da yer verdiğini vurgulamıştır. Bu konuda tüm yanıt veren ülkelerin genelinde öne çıkan kavramlar; yetenek bilgisi, istihdam edilebilirlik, yaşam boyu öğrenme, eğitim, mesleki rehberlik gibi kavramlardır. Türkiye, yeteneksiz ya da düşük yetenekli kişiler için turizm endüstrisinde işbaşı eğitimler olması gerektiğini belirtmiş, yeteneklerin arttırılması yönünde hali hazırda çalışmalar içinde olduğunun altını çizmiştir (UNWTO, 2010). Yeteneklerin arttırılması, geliştirilmesi, yeni yeteneklerin mevcut yeteneklere ilave edilmesi ya da yetenek kazandırılması yoluyla turizm endüstrisi teknolojik tehditlerden etkilenmeyecek ve çalışmanın geleceğinde istihdam edilen kişiler de çağa uyumlu yetenekleri sayesinde endüstriye faydalı olabileceklerdir.

\section{Sonuç ve Öneriler}

1919 yılında kurulan UÇÖ, 2019 yılında 100. yılını kutlarken çalışmanın geleceği kavramı üzerinde durmuştur. Kavram, Endüstri 4.0 kapsamında robotların, yapay zekânın ve otomasyonun gelecekte istihdamda insanların yerini alacağı temeli üstüne üç ana başlıkta ele alınmıştır. Bu başlıklar, insanların kapasitesinde yatırımların arttırılması, işyerlerinde yatırımların arttırılması ve insan onuruna yakışır ve sürdürülebilir çalışma yatırımlarının arttırılması şeklindedir. Bu bağlamda bahsedilen insan onuruna yakışır iş kavramı ilk defa 1999 yılında UÇÖ tarafindan dile getirilmiştir. Kavram temelinde dört hedef içermektedir. Bu hedefler, iş yerindeki temel ilkeler ve haklar, daha fazla istihdam, sosyal koruma ile sosyal diyalog - temsil edilebilirlik- hedefleridir. Bir işin insan onuruna yakışır iş olup olmadığının ölçülebilmesi için geliştirilen modeller, ortak noktada bu hedefleri içermekle birlikte, yeteneklerin geliştirilmesi gerektiğine dair gösterge ilk oluşturulan modellerden birinde ele alınmış ama son kabul edilen modelde yer almamıştır. Halbuki yetenek geliştirme, insanlardaki mevcut yeteneklerin tespit edilmesinden gelecekte oluşacak yeni işler ve meslekler veya değişim geçirecek işler için yeni yeteneklerin geliştirilmesine kadar geniş bir yelpazeyi kapsamaktadır. Zira Endüstri 1.0'dan itibaren insanların istihdamda yer alabilmeleri için sahip olmaları gereken yetenekler zaman içinde yerlerini yeni veya geliştirilmiş yeteneklere bırakmışlardır. Örneğin eskiden sadece fiziksel yeteneklerle yapılabilen bazı işler tamamen ortadan kaybolmuş, teknoloji geliştikçe yeni işler yeni yetenekleri doğurmuştur. 
Turizm endüstrisi, yeni yeteneklere ihtiyaç duyan ve duyacak endüstrilerden biridir. İnsan odaklı bir endüstri olan turizm endüstrisinde istihdam, teknolojilerin yarattığı robotlar, bulut teknolojiler, internet, sosyal medya, otomasyon gibi gelişmeler yüzünden tehdit altındadır. İnsan onuruna yakışır iş bakımından analiz edildiğinde de gerek çalışma koşulları ve ücretler, gerekse sosyal diyalog ve kadın-erkek eşitliği açılarından da olumlu bir tablo çizmemekte olan endüstride çalışmanın geleceği kapsamında yetenekleri geliştirici önlemler alınmazsa, istihdam yerini gelecekte yapay zekâya ve robotlara birakacaktır.

Dolayısıyla bu doğrultuda turizm bölümleri müfredatlarına zorunlu olarak yaratıcılık ve girişimcilik gibi metodolojik yetenek içeren dersler, liderlik gibi sosyal yetenek içeren ders, kodlama gibi teknik yetenek içeren ders ile öğrenme motivasyonu gibi bireysel yetenek içeren dersler dengeli dağılım içinde olmalıdır. Kısacası müfredatları sadece sosyal ya da teknik yetenek içeren derslerle değil tüm yetenekleri geliştirebilecek derslerden oluşturmak faydalı olacaktır. Ayrıca kodlama, yapay zeka, robot teknolojileri, otomasyon gibi yüksek lisans programlarının oluşturulması ve başvuruların turizm bölümü mezunları gibi sosyal bilimler mezunlarına da açık olması, gelecekte kaybolma tehdidi altında olan meslekler için turizm endüstrisine alternatif çözüm olabilecektir. Bu hususta, Kültür ve Turizm Bakanlığı ile Sanayi ve Teknoloji Bakanlığı arasında ortak projeler yapılması için zemin hazırlanmalı ve üniversiteler tarafindan da bu projeler desteklenmelidir.

Hakem Değerlendirmesi: Dış bağımsız.

Çıkar Çatışması: Yazar çıkar çatışması bildirmemiştir.

Finansal Destek: Yazar bu çalışma için finansal destek almadığını beyan etmiştir.

Peer-review: Externally peer-reviewed.

Conflict of Interest: The author has no conflict of interest to declare.

Grant Support: The author declared that this study has received no financial support. 


\section{Kaynakça/References}

Anker, R., Chernyshev, I., Egger, P., Mehran, F., \& Ritter, J. A. (2003). Measuring decent work with statistical indicators. International Labour Review, Geneva, 142(2), 147178.

Bescond, D., Chataignier, A., \& Mehran, F. (2003). Seven indicators to measure decent work: An international comparison. International Labour Review, Geneva, 142(2), 179-212.

Bonnet, F., Figueiredo, J. B., \& Standing, G. (2003). A family of decent work indexes. International Labour Review, Geneva, 142(2), 213-238.

Phillpott, S. (2017). Career Addict. 13 Disapperaring Jobs That Won't Exist in 2030. https://www.careeraddict.com/disappearing-jobs

Closing the Skill Gap. https://www.closingtheskillsgap.org/ file://E:/FUTURE\%20 OF\%20WORK/ROBOTICS/Closing\%20the\%20Skill\%20Gap\%20_\%202020.pdf

Dautovic, G. (2019). Automation and job loss statistics in 2019- The robotsa are coming, file://E:/FUTURE\%20OF\%20WORK/ROBOTICS/Automation $\% 20$ and $\% 20 J$ ob $\% 20$ Loss\%20Statistics\%20in\%202019\%20-\%20The\%20Robots\%20Are\%20Coming.pdf

European Commision. Threats and opportunities from automation and robotisation. https://ec.europa.eu/ file://E:/FUTURE\%20OF\%20WORK/ROBOTICS/Threats\%20 and $\% 20$ opportunities $\% 20$ from $\% 20$ automation $\% 20$ and $\% 20$ robotisation $\% 20 \_\% 20$ Knowledge\%20for\%20policy.pdf

Ghai, D. (2003). Decent work: concepts and indicators. International Labour Review, 142(2), 113-145.

Global Commission. (2019). Work for a brighter future. ILO Publications, file://E:/ FUTURE\%20OF\%20WORK/wcms_662410.pdf

Gurun, F. (2019). Endüstri 4.0. ve beşeri sermayenin geleceği. Sosyal Siyaset Konferanslarl Dergisi, 76, 67-88.

ILC 87. Decent work, file://E:/FUTURE\%20OF\%20WORK/ILC87\%20-\%20Report\%20 of $\% 20$ the $\% 20$ Director-General_\%20Decent\%20work.pdf

ILC 108. ILO centenary declaration for the future of work adopted by the conference at its one hundred and eighth session, Geneva, file://E:/FUTURE\%20OF\%20WORK/ wcms_711674.pdf

ILO. Decent work, https://www.ilo.org/global/topics/decent-work/lang--en/index.htm

ILO. Future of Work Issue Briefs, file://E:/FUTURE\%20OF\%20WORK/Future\%20 of $\% 20$ Work $\% 20$ Issue $\% 20$ Briefs $\% 20$ (The $\% 20$ future $\% 20$ of $\% 20$ work).pdf

ILO. History of ILO, file://E:/FUTURE\%20OF\%20WORK/ILO $\% 20 \operatorname{tarih} \% \mathrm{C3} \% \mathrm{~A} 7 \mathrm{e}$. pdf

ILO. (2015). The future of work centenary initiative. International Labour Conference. 104th session, file://E:/FUTURE\%20OF\%20WORK/wcms_369026.pdf 
ILO. (2017). 2nd meeting of the Global Commission on the future of work. Cluster 3:Technology for social, environmental and economic development. Issue brief 6. https://www.ilo.org/wcmsp5/groups/public/---dgreports/---cabinet/documents/ publication/wcms_618168.pdf

ILO. (2019). Report IV. ILO centenary outcome document. file:///E:/FUTURE\%20 OF\%20WORK/wcms_700622.pdf

ILO. (2019). The future of work centenary initiative, issue note series 1 . Technological changes and work in the future. file://E:/FUTURE\%20OF\%20WORK/EN\%20 ÖNEMLI\%20KAYNAK-ILO\%20TECHNOLOGY\%20JOBS.pdf

ILO. ILO'nun tarihçesi, https://www.ilo.org/ankara/about-us/WCMS_372874/lang--tr/ index.htm

ILO. ILO nasıl çalışır?, https://www.ilo.org/ankara/about-us/WCMS_372875/lang--tr/ index.htm

ILO Manual. (2013). Decent work indicators. ILO Publications, Geneva.

Ivanov, S., Gretzel, U., Berezina, K., Sigala, M., \& Webster, C. (2019). Progress on robotics in hospitality and tourism: a review of the literature. Journal of Hospitality and Tourism Technology (forthcoming).

Ivanov, S. ve Webster C. (2017). Adoption of robots, artificial intelligence and service automation by travel, tourism and hospitality companies - a cost-benefit analysis. International Scientific Conference "Contemporary tourism - traditions and innovations", 19-21 October 2017, Sofia University.

Manyika, J. (2017). Technology, jobs and the future of work. file:///E:/FUTURE\%20 OF\%20WORK/ROBOTICS/Technology, $\% 20$ jobs, $\% 20$ and $\% 20$ the $\% 20$ future $\% 20$ of $\% 20$ work\%20_\%20McKinsey.pdf

McKinsey\&Company. (2018). Automation and the future of the workforce. Discussion paper. file://E:/FUTURE\%20OF\%20WORK/ROBOTICS/Automation\%20and\%20 the $\% 20$ workforce $\% 20$ of $\% 20$ the $\% 20$ future $\% 20$ \%20McKinsey.pdf

MIT. (2019). The work of the future: shaping technology and institutions. Fall 2019 report. file:///E:/FUTURE\%20OF\%20WORK/ROBOTICS/WorkoftheFuture Report_Shaping_Technology_and_Institutions.pdf

Nübler, I. (2016). New Technologies: a jobless future or golden age of job creation? ILO Research Department Working Paper 13, file://E:/FUTURE\%20OF\%20WORK/ ROBOTICS/wcms_544189.pdf

OECD. The OECD jobs strategy. Technology, productiity and job creation, best policy practices. Highlights, file://E:/FUTURE\%20OF\%20WORK/ROBOTICS/2759012.pdf

Palaz, S. (2005). Düzgün iş kavramı ve ölçümü: Türkiye ve OECD ülkelerinin bir karşılaştırması. İÜ Dergi, 50, 479-505.

REVFINE. https://www.revfine.com/robots-hospitality-industry/

Sar1, E. B. (2018). Reflections of industry 4.0. to management of service enterprises:smart hotels. International Journal of Contemporary Tourism Research, 2, 33-40. 
T.C. Aile, Çalışma ve Sosyal Hizmetler Bakanlığı. (2018). Çalışma Genel Müdürlüğü. Çalışma hayatı istatistikleri 2017, https://www.ailevecalisma.gov.tr/media/3302/ calisma_hayati_2017.pdf

Turner, R. (2018). Travel\&Tourism Economic Impact 2018 World. WTTC.

TÜİK, İşgücü İstatistikleri, http://www.tuik.gov.tr/PreTablo.do?alt_id=1007

TÜİK, İşgücü Maliyeti, http://www.tuik.gov.tr/PreTablo.do?alt_id=1008

Tüzünkan, D. (2015). Türkiye'de turizm sektöründe istihdam politikalarının insan onuruna yakışır iş bakımından incelenmesi. Yayımlanmamış doktora tezi. İstanbul Üniversitesi Sosyal Bilimler Enstitüsü, İstanbul.

UNWTO. (2010). Questionnaire on tourism and employment: overview of results UNWTO statistics and tourism satellite account (tsa) programme room document. 2nd T.20 Ministers Meeting, Republic of Korea, 11 - 13 October 2010 file://E:/ FUTURE\%20OF\%20WORK/ROBOTICS/unwtoemployment.pdf

Ünlüönen, K. ve Şahin, S. Z. (2011). Turizmde istihdam. Elektronik Sosyal Bilimler Dergisi, 10(37), 1-25.

World Tourism Organization and International Labour Organization (UNWTO). (2014). Measuring employment in the tourism industries - guide with best practices, Madrid. 
